Caste-Gender Intersections in Contemporary India

\title{
Towards a Horticultural Society: Class, Caste and Masculinities in Rural Andhra Pradesh
}

\section{Nilotpal Kumar}

\section{(2) OpenEdition}

\section{Journals}

\section{Electronic version}

URL: http://journals.openedition.org/samaj/4829

DOI: $10.4000 /$ samaj.4829

ISSN: $1960-6060$

\section{Publisher}

Association pour la recherche sur l'Asie du Sud (ARAS)

\section{Electronic reference}

Nilotpal Kumar, «Towards a Horticultural Society: Class, Caste and Masculinities in Rural Andhra Pradesh », South Asia Multidisciplinary Academic Journal [Online], 19 | 2018, Online since 17 October 2018, connection on 01 May 2019. URL : http://journals.openedition.org/samaj/4829; DOI : 10.4000/ samaj.4829

This text was automatically generated on 1 May 2019.

\section{$(1) \Theta \Theta$}

This work is licensed under a Creative Commons Attribution-NonCommercial-NoDerivatives 4.0 International License. 


\title{
Towards a Horticultural Society: Class, Caste and Masculinities in Rural Andhra Pradesh
}

\author{
Nilotpal Kumar
}

\section{Introduction}

1 India witnessed a deceleration in the growth rates of the area, production, and yield of many conventional food and cash crops between the late 1990s and early 2000s (Kannan and Sundaram 2011; Chand, Raju, and Pandey 2007). Since 2003-04 agricultural growth has recovered to pre-1990 levels, but research suggests that small and marginal farmers cultivating under rain-fed conditions continue to deal with low and stagnant incomes (e.g. Lerche 2015). The area devoted to horticulture in the country has, in contrast, grown by 151 per cent since 1990 and horticultural production has more than trebled (Government of India 2014). By 2013-14, horticulture's share in the gross value of agricultural output was about 25-30 per cent. Fresh fruits and vegetables constitute 60 and 31 percent of all horticulture products respectively, and the lions' share of fruits being cultivated now consists of banana, mango and citrus (Government of India 2014). This horticultural expansion seems to have had a pan-Indian sweep but Maharashtra and Andhra Pradesh have been prominent in fruit cultivation while West Bengal and Bihar have moved towards vegetable cultivation (Government of India 2014; Joshi et al. 2004:2460).

2 Neo-liberal economic writings have welcomed this expansion as a process of "rural diversification" in which small farmers reallocate resources from "low-value" green revolution grains and other conventional cash crops into "higher-value" fruits and vegetables (e.g. Joshi et al. 2004; Chand et al. 2007; Fan and Gulati 2007; World Bank 2008). They see the adoption of horticulture as a response to a diversification in food consumption both nationally and internationally, which is catered to by private capitalled supply chains (e.g. Government of India 2017). Notwithstanding this belief in 
smallholders' rationality and commercial viability, some influential writings (e.g. World Bank 2008) also suggest that "uncompetitive" smallholders "exit" agriculture to pave the way for direct corporate farming. While there is little doubt that agricultural productivity needs substantial improvement in India, the neoliberal orthodoxy naturalizes the fact that the decline in value of many conventional crops occurs on account of the particular farm policies adopted since 1991 (Alagh 2006:212-13).

3 A contrasting interpretation of the phenomenon has emerged from Marxist agrarian political economy. According to it, the promotion of horticulture in developing countries is a "case" of the world-historical "restructuring" of commodity production under neoliberal reforms since the 1980s (Akram-Lodhi and Kay 2010; Friedmann 1993; Watts 2010; Banaji 1996). The substitution of conventional food and cash crops for horticulture represents the reformist fetish for export-oriented agriculture in the global south. But this fetish facilitates greater capitalization of small-scale production through input and output markets that are increasingly controlled by international agrobusinesses (e.g. Little and Dolan 2011). In reference to India, there are disagreements about whether Indian farmers suffer more under the yoke of global agribusinesses or their "home-grown masters" (Harriss-White 2008), but this scholarship views horticultural restructuring essentially as a process of radical subordination of the production choices of small peasants to corporate capital without their receiving the promised economic benefits (Lerche 2015).

4 Unlike these two positions that often operate on a global scale and assume local agrarian realities as their representations, this paper seeks to scrutinize horticultural restructuring from the vantage of a specific place, a village named NRP in the semi-arid Anantapur district of Andhra Pradesh in South India (Map 1). ${ }^{1}$ My focus here is not the local economics of horticulture. I describe how horticulture shapes and is itself shaped by the historically configured intersectionality of class, caste, and gender, interacting with a semi-arid ecological setting. Drawing loosely on the Marxist political economic usages of class, particularly in Terence Byres's (1995) sense, according to which agrarian transitions reflect historically specific configurations of social classes and their relationships to the state, I suggest that horticulture in Anantapur has reinforced the economic position of pioneering large and middle-sized farmers with access to well-irrigation to the detriment of late-coming dry smallholders; these smallholders lack the capacity to shift to horticulture due to the ruinous cost of groundwater. Thus, in the local complex of caste, the dominant middle -caste Reddys and a few Kuruba farmers (an Other Backward Caste $[\mathrm{OBC}]$ that is prominent locally) appear to have maintained their economic advantages, while most small $\mathrm{OBC}$ dry-land farmers, the late-coming aspirants, face steeper gradients of adversity in horticulture. These dynamics of class and caste relations within agriculture also work themselves out at the level of gender; the aspiring dry-land $\mathrm{OBC}$ farmers tend to conceive of horticulture as a key sub-field in which to mobilize their economic and cultural resources, perform as "virile farmers," and to transact honor with established horticulturists and other dry-land farmers within and across castes.

5 The paper is organized in three sections. I begin with an overview of how Anantapur's socio-spatial context and its colonial history have affected each other, and how they continue to influence the post-colonial rural society of the district; the second section explores how the local class and caste divisions have interacted in the post-independence period, particularly since 1991, while the third section aims to understand how local OBC farmers use horticulture in their speech acts and practices to engender themselves as 
virile farmers. My empirical data comes from ethnographic work conducted between January 2005- March 2006, and from multiple short trips afterwards. This ethnography includes a year-long study of agricultural activities amongst a sample of 31 households (17 per cent of all cultivating households) selected through a stratified random sampling method (see Kumar 2017).

\section{Anantapur: outlines of a fragile social-ecology and its colonial history}

6 Anantapur peasants typically speak of their district and Rayalaseema ${ }^{2}$ as a karavu prantham-a "dry and scarcity-prone zone." Such a representation of the district appears to convey modified appraisals of "dryness" and "scarcity" locally, but if we focus on physiographical aridity, the district receives $553 \mathrm{~mm}$ in average precipitation which is the lowest precipitation of all districts in AP and the second lowest in India. This rainfall is marked by significant annual, intra-seasonal and regional variations as well. Between 1901 and 1998, on average, almost every third year was a rain-scarce year when precipitation fell 10 to 46 per cent below the statistical average. Even a statistically normal rainfall year shows moisture variations during mid-June to mid-August, significantly affecting sowing activities and yields of the kharif (monsoon) crop. Additionally, the regional gradient of rainfall is such that the central hilly uplands of Anantapur, which is where NRP village is located, receive only $335-350 \mathrm{~mm}$ annually. Having said this, historical research has underlined a "progressive desiccation" of Anantapur since the late $19^{\text {th }}$ century, from which period farming has pushed into the extensive dry deciduous forestlands that once covered much of the Rayalaseema region (Ludden 1999:58). ${ }^{3}$

Map 1 (Anantapur location)

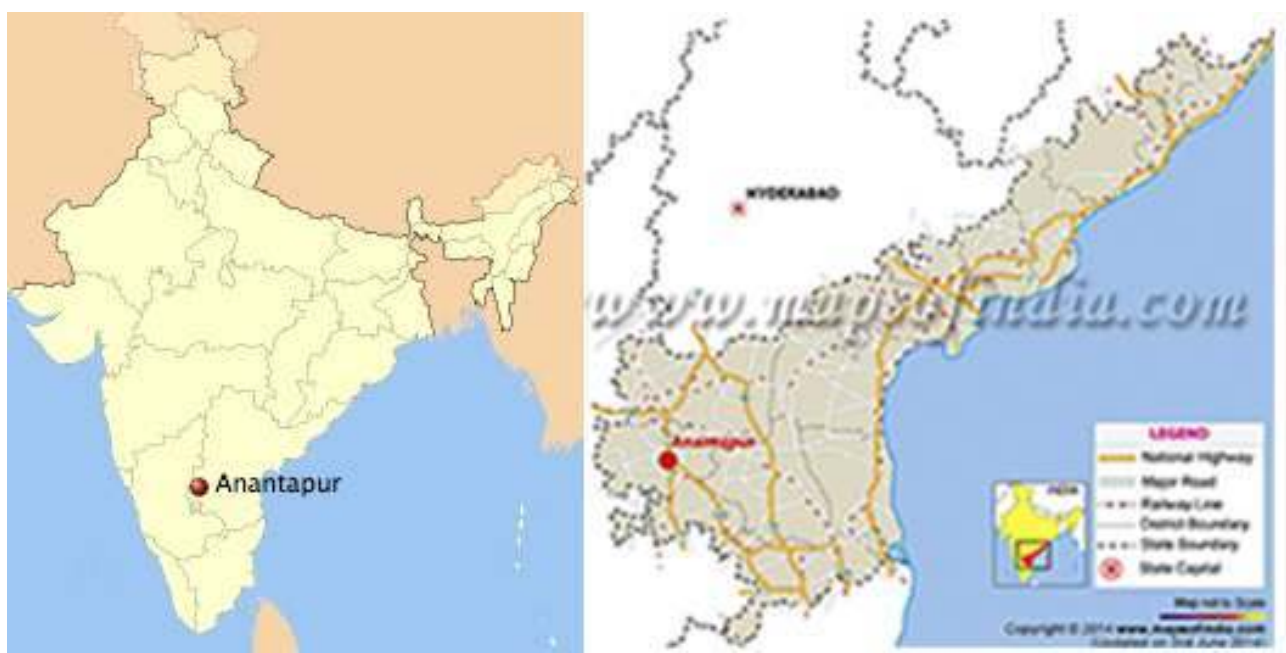

7 While Anantapur's geographical location influences the amount of precipitation it receives today, the local physiographical features impair the collection and distribution of sub-surface and groundwater. The rivers that drain the district, including Pennar, are rain-fed, with highly variable water levels in their upland courses. The local topography and water-scarcity may have been the chief obstacles in developing canal irrigation in the district (Alaev 2012:226; Whitecomb 2005:706, 710). As late as 2012-13 the net area under 
canal irrigation in Anantapur was a mere 15 per cent of the net irrigated area in the district. In comparison, the district has long had an extensive network of water tanks courtesy of the Vijayanagar rulers: Francis (1905) cites a revenue settlement of 1890s that estimated the number of large tanks in the district to be around 700 (p. 63). But coming round to 2010-11, the 1,259 officially listed tanks alongside spring channels and rivulets were irrigating a mere 18 per cent of their registered ayacut (Chief Planning Officer 201011: Table 5.2). Anantapur has thus witnessed the same pattern of the declining importance of tanks as a source of irrigation that has been reported from much of South India (Shankari 1991). This neglect of the tank system has been attributed to growing human intervention in local watersheds and silting, but it also seems that the rise of wells as a major source of private irrigation, which was promoted by the colonial state throughout the dry Deccan from late $19^{\text {th }}$ Century, gave rise to this neglect (Whitecomb 2005:722).

It can also be suggested in hindsight that the thrust of the colonial and post-colonial policies regarding the exploitation of groundwater-in isolation from other water bodies -in Deccan could not fully take into account the particularities of the local hydrology. The district is situated in a geological zone comprising largely un-fractured granite formations (Karanth 1987:420-24), which have low primary porosity and slow recharge, and the presence of aquifers amongst them is restricted within small fractured zones. At the outset of my research in 2005, out of 45 shallow wells that existed in the village with depths reaching up to 50 feet, 28 had either gone completely dry for years or remained dry all year except in the Monsoon period. Likewise, in 2005 most local farmers agreed that the stable aquifers for bore-wells could be accessed around 90-125 feet below ground level (bgl), but by 2014-15 the attempts for groundwater-including those for drinking purposes-were reaching aquifers 400 feet bgl. The general point that emerges here is that Anantapur's hydrological resources have been historically poorer than those of other regions in dry southern Deccan (e.g. Farmer 1977:10), or the arid North Gujarat area (Dubash 2004:225), and yet, the local pattern of sub-surface and groundwater usage has degraded them in a way that resembles the depletion reported from other dry regions in the country (Dubash 2004; Harriss-White, and Janakarajan 1997).

In the wake of the district's aridity, the lands of the district are impoverished in biomass. Shallow red soils and scrublands around hills are characteristic of much of Ananatapur barring the Northern lowlands. Up until the mid- $19^{\text {th }}$ century much of the marginal tracts of Rayalaseema remained sparsely occupied, and according to Dharma Kumar (1992) they were available for cultivation on the payment of land revenue under the Ryotwari settlement although the revenue now being asked for was extremely high (pp. 29-30). Relatively more fertile lands including well-irrigated garden lands (thota) in watershed areas had largely been colonized by then by "warrior-caste farmers" (Ludden 1999:91) such as the Reddys; such castes had benefitted from the political chaos that had marked the two centuries between the decline of Vijayanagar empire and the entrenchment of British rule. Reddy landlords, and possibly smaller Reddy proprietors too, cultivated their farms by employing the local landless Dalit castes of the Malas (traditionally weavers) and Madigas (traditionally leatherworkers [Kumar 1992:47, 61]). Thus, as Dharma Kumar and David Washbrook both emphasize, by the 1850s, the basic outlines of an emerging agrarian social structure were visible in the interior Deccan; a Reddy gentry was forming at the core of this structure, with a layer of smaller proprietors and tenants (raiyats) who cultivated their dry lands and gardens with labor from the Malas and Madigas. However, 
these scholars underline that the agrarian caste hierarchies and identities in Rayalaseema were milder than those developed in tropical South India, and that they have remained so throughout the 20th century (Kumar 1992:46-47; Washbrook 1975:168-69).

As the colonial regime of governance expanded, these structural outlines deepened and acquired multi-dimensional hues. Economically, Washbrook (1994) has associated the period between 1870 and 1930 in Bellary-Anantapur districts with a "crisis in production and social reproduction" (p.132). The number of registered dry land pattas (titles) proliferated from the 1880s onwards, largely on the back of the sedentarizing middle castes of Kurubas (traditionally shepherds) and Boyas (earlier hunters-warriors) who were now cultivating the cash crops of cotton and groundnut to pay land-rents (Kumar 1992:47; Thurston [1909] 2001). Washbrook (1973; 1994) also argues that many attached Malas and Madiga laborers compulsively took pattas to move into cash cropping as their employers-the Reddy landlords-began laying them off to benefit from soaring grain prices in this period. Anantapur agriculture was thus fairly smallholder oriented and commoditized by 1900 , with $20-25 \%$ landless laborers, but this smallholding class depended on Reddy landlords for credit in order to produce cash crops under conditions of uncertain rainfall (Washbrook [1976] 2008:68-77). Larger landlords/moneylenders increasingly ploughed their surpluses from production and moneylending into new urban ventures such as mining, civil contracting, liquor businesses, banking and politics (Washbrook [1976] 2008:153). But a more important point is that they used their economic clout to consolidate local power, notably through the office of the village headman (Reddy). It was a position they had historically held but now it was also the central institution of bureaucratic powers and privileges including that of petty policing, arbitrage, and revenue administration (Washbrook [1976] 2008:148-51). A new logic of rural politics, governance and culture thus emerged in the region circa 1900 in which resourceful rural landlords competed to expand their local control by cultivating dependents and subordinating rivals in a number of ways, including organized violence (Washbrook 1973:498).

11 The intensification of farming in a marginal ecology was also the context in which Rayalaseema became the scene of consistent agrarian crisis in the late $19^{\text {th }}$ century. Between 1803 and 1886, the Bellary-Anantapur districts went through eight major famines, amongst which the most notable was the famine of 1876-78 that saw one-fourth of the district's population perish (Washbrook 1994:131). Although the failure of monsoons often triggered these famines, as happened in the 1876-78 catastrophe, historical evidence suggests that the post- 1850 famines in Rayalseema broadly coincided with the expansion of commercial crops in place of millets, which were now being traded robustly-often in speculation-in the growing internal grain markets in the country. Washbook ([1976] 2008:77) and Satyanarayana (2005:207) have reported steep fluctuations in millet prices in dry Deccan through the 1880s to 1920s, sometimes to the tune of $30 \%$ from month to month, causing repeated "famine prices" in these districts. Arnold (1998:82-83) has similarly underlined the "advanced state of indebtedness" amongst small peasants by the 1870 s, which led to the abandonment of cultivation on roughly 3.25 million acres of newly colonized marginal lands during the 1876-78 famine. Two general points emerge from this review of historical literature: (1) from being a hub in the south Indian textile production and exchange network in early $18^{\text {th }}$ century, Anantapur had become one of the most agriculture-dependent spaces in South India by mid- $20^{\text {th }}$ century (Ludden 1999:139, 146); (2) class (and caste) differentiations intensified in the local society 
during this period, with a small gentry (predominantly Reddys) growing in its economic and administrative clout over other villagers occupying various class (and caste) positions in the local hierarchy.

\section{Postcolonial developments: classes, horticulture and the "bore-well rush"}

The historical process of production expansion in marginal dry lands has continued postindependence but possibly at an attenuated rate. Between 1997-98 and 2010-11 approximately 16 per cent of "uncultivated wasteland" in the district (as of 1997-98) had been brought under cultivation. This expansion has contributed to reduced landlessness in NRP (less than 10 per cent; Table 1). At the same time, both in NRP and in the district as a whole the pronounced trend concerning landholdings has been the miniaturization of plots. In 2005 an average dry-land unit in the village was 6.56 acres, ${ }^{4}$ and units up to 5 acres constituted 57.07 per cent of all village holdings. Only 15.12 per cent units were medium or large (i.e., 9.88 acres to 49.41 acres $^{5}$ ). Miniaturization has surely muted the relative inequalities of landholding but it has not eliminated them. Table 1 below demonstrates that the Reddys, although numerically insignificant in the village, still hold a large share of village lands; one Reddy family of 7 fraternal kinsmen in particular, bearing the clan name of Tupakula (the "gun"), comes somewhat close to reflecting Washbrook's (1976) notion of "village-local boss" (p. 770), with about 200 acres of land in the family. An average Reddy landholding is about four times the size of a Madiga (now a Scheduled Caste) landholding, and more than twice that of a Kuruba (now a Backward Caste). But the real cornerstone of Reddy economic clout in the village has been their longtime ownership of wells; all Reddy households except one have had access to wells, and the Tupakula family, constituting just about 3 per cent of all landowning households, has had access to 20 per cent of all field wells in the village (Table 2). In contrast, only 7 Madiga households out of 56 households ( 12.5 per cent) had any access to wells. The numerically dominant Kurubas, and all Ekilas (who were included in the official list of "backward castes" in 2008) have occupied a middle to marginal position in the hierarchy of access to water, the former being the 47 Kuruba households that have had access to wells for decades.

In a regime of relatively broad-based land distribution with unequal ownership of wells, the local dry land farmers have been cultivating groundnut during kharif for over a century: if they were the Kurubas, they would farm ruminants or weave clothes in addition. Households with wells, on the other hand, have conventionally double-cropped groundnut in upland thota, and paddy in lowland garden lands. Groundnut requires low levels of moisture (400-450 mm), and manual labor, particularly family labor, can be used for weeding and harvesting, making the crop so popular as to have almost replaced dry millets in the district. ${ }^{6}$ After witnessing remarkable growth from 1981-82 until 1993-94 in terms of area, productivity and profitability, possibly due to "green-revolution" technologies integrating dry land agriculture by the 1980s, groundnut production has hit sustained deceleration in the state (Subramanyam and Sekhar 2003). NRP provides good evidence of this crisis. In 2005-06, a normal rainfall year, the kharif groundnut yield per acre had ranged between $225 \mathrm{~kg}$ to $287 \mathrm{~kg}$, which was markedly lower than the average yields achieved in the district throughout the $1990 \mathrm{~s}(296.35 \mathrm{~kg}$ in $1988-92,355.78 \mathrm{~kg}$ in 1996-20017). Although all classes of farmers managed to make profit in 2005-06, the profit 
margins were so slim for the marginal and small farmers (predominantly the Kurubas and Madigas) that even a slight fall of 10-20 per cent in output could have wiped them out. Kharif outputs have been increasingly plagued by weather and disease-induced variability while outlays on commercial inputs have risen in the last decades as the state has steadily withdrawn input subsidies along with reducing investments in research and extension services (Ghose 2005:1035). If groundnut output prices do not continuously rise or if farmers do not switch to thota cultivation, it will be difficult to derive a good return from the crop. However, here as well, with post-trade liberalization, groundnut output prices have been dampened by an import-dominant edible-oil market.

\begin{tabular}{lccccc} 
Table 1 & \multicolumn{5}{l}{ NRP; landholding and its distribution } \\
\hline Caste & $\begin{array}{c}\text { Households } \\
\text { (No.) }\end{array}$ & $\begin{array}{c}\text { Landholding } \\
\text { (Acres) }\end{array}$ & $\begin{array}{c}\text { Landless } \\
\text { (No.) }\end{array}$ & $\begin{array}{c}\text { (household) } \\
(\%)\end{array}$ & $\begin{array}{c}\text { land holding } \\
(\%)\end{array}$ \\
\hline Kapu & 16 & 251.5 & - & 7.07 & 16.95 \\
Ekula & 30 & 186 & - & 13.27 & 12.54 \\
Vaishya & 01 & 00 & 01 & 0.44 & -- \\
Kuruba & 100 & 699 & 10 & 44.24 & 47.14 \\
Boya & 07 & 67.6 & - & 03.09 & 4.55 \\
Chakali & 05 & 13 & 02 & 2.21 & 0.88 \\
Dudekula & 08 & 35 & 01 & 3.53 & 2.35 \\
Madiga & 56 & 221 & 06 & 24.77 & 14.90 \\
Mala & 01 & 05 & - & 0.44 & 0.33 \\
Erikula & 01 & 00 & 01 & 0.44 & -- \\
Ediga & 01 & 05 & - & 0.44 & 0 \\
\hline Total & 226 & 1483.1 & 21 & 100 & 100 \\
\hline
\end{tabular}

Village Census Survey, 2005-06

14 A common response of the local peasants to the non-viability of kharif groundnut has been to attempt switching over to Batavia, or ceenakai in Telugu, by investing in borewells. The crop grows well in shallow soils and it takes five years to yield the first harvest, during which period investments on inorganic inputs are relatively small, and farmers often intercrop it with groundnut for the first three years to minimize their waitingperiod income losses. Based on my rough estimates of crop-yield as reported by the local farmers, at 2016-17 prices per acre, annual gross returns from Batavia worked out to be around Rs. 3,000,000, which was more than twice the returns that were being obtained by large and middle-sized farmers from their best double-cropped groundnut yields per acre (see also Kumar 2017:68). It is not surprising therefore that from just 234 hectares in 1999-2000, the acreage devoted to the crop rose to 1,522 hectares in the mandal (the revenue and administrative unit of which NRP is a constituent) by 2010-11, and by the same year Anantapur had emerged as the second largest grower of Batavia in AP in terms of area. In NRP 78 per cent of thota-owning households had Batavia orchards at different stages of growth by 2005-06. However, the crop requires a secured and gradually increasing amount of moisture (as its canopy grows) from the fifth year onwards through the fruit-bearing span of about 15 years of the crop. Despite being known to be remunerative, Batavia cultivation had therefore been restricted to the groundwater rich mandals of the district (Satyanarayana 1965:197). With bore-wells revolutionizing groundwater extraction in the district, and with subsidized micro-irrigation technology automating and rationalizing irrigation, Batavia is now a high-risk but high-profit venture for local farmers.

15 This requirement of having a bore-well has also rendered horticulture an exclusive field of participation in the village. In 2005 only $34 \%$ of all landowning households had any access to groundwater, and the gross irrigated acreage under bore-wells was just $14 \%$ of 
the gross cropped area of the village. Horticulturists across classes and castes hence form a select group that is acknowledged locally as "cinathota raithlu" (Batavia farmers), but it is also clear to the villagers that this group is heterogeneous from within in many senses; it consists of the pioneers, the 5 households of the Tupakula family, ${ }^{8} 2$ wealthy Kuruba households and 1 Ekila, all of whom had their well-thota close to the village (hence energized much earlier), and who turned these into Batavia orchards between 1986 and 1990. These pioneers, the "pata-thota-walu" (old horticulturists), were followed by more well-owning middle peasants from Reddy and Kuruba castes between 1995 and 1999. It is since 2000 that the largest number of dry-land owning small landholders from Kuruba and Ekila castes have been making attempts at sinking bore-wells to turn to horticulture. A sign of the socially differentiated movement lies in the timeline of the first successful bore-well drilling attempt, which is a proxy for horticulture, amongst a random sample of 31 farming households that I studied in 2005-06; out of the 20 peasants ( 65 per cent) who had made an attempt at sinking bore-wells, 5 had made their first attempt between 198590, another 5 between 1990 and 2000, but the remaining 10 had done so since 2000 . Amongst the 11 households that had not yet attempted a bore-well, all except one were the Madiga smallholders.

Some distributional features of the process of "double restructuring"-i.e. the movement from shallow wells to bore-wells and from groundnut to horticulture-underway in NRP may be underlined given their analytical importance. A majority of functioning borewells in 2005 (70 per cent) were now owned by individual households, reducing the overall number of households with access to groundwater in the transition (Table 2). In other words, many pioneers have made subsequent attempts at rigging bore-wells to consolidate their access to groundwater, in order to expand the scale of their horticulture, whereas many former well-owners have lost out on access to groundwater completely. Caste-wise, a concentration of groundwater has occurred amongst the Reddy households; the Ekilas, who have been the latest entrants in the official list of the "backward castes," have gained more than they have lost in the process. It is amongst the Kurubas, demographically the largest backward caste in the village (and in the mandal), that most households have lost access to groundwater in the last decade, making intracaste and intra-kin differentiation sharper now. The Madigas have not participated in horticulture; they have continued working in on-farm and/or off-farm labor markets. Lastly, it is the middle and large landholders amongst the Reddys and Kurubas who have benefitted from this double restructuring.

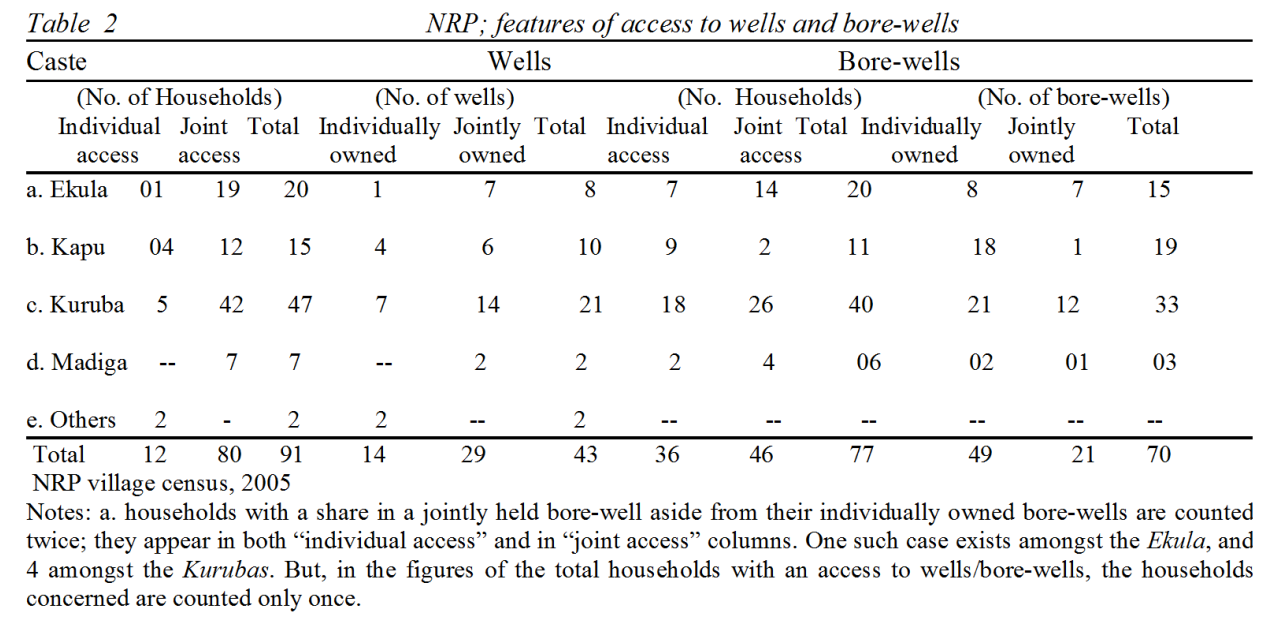


In pro-reform economic writings that advocate crop diversification on the basis of finding a positive relationship between diversification and rural growth, such increased private expenditure on groundwater is seen as a validation of the small farmers' rationality to choose new activities with higher "factor returns" over old ones (e.g. Joshi et al. 2004). Indeed, with the claim of being a top-producer district of fruits in the state as the result of such rationality, one might think of Anantapur agriculture as moving up the ladder of production activities that are known to result in the emergence of interdependent clusters of urban-rural growth in the Punjab state of India or in China (Kotwal and Ramswami 1998). But such a perspective on diversification disregards the impact of historically shaped social structures on current ecological and social costs of private investment in irrigation in dry-land areas. In 2005 when groundwater level was still relatively high in the village and the cost of drilling low, each bore-well drilling attempt (up to 200 feet bgl) cost Rs. 11-11,500, but it had risen to Rs. 16,000 on an average by mid-2015. Even in the relatively favorable hydrological conditions of 2005, the small farmers in the studied sample had made 3-4 attempts per household on an average in the preceding five years (costing altogether approximately Rs.50,000 per household), spending close to 50 per cent of all their capital expenditure just on successful bore-wells, and another 30 per cent on attempts that failed to strike water either at the time of sinking or, much worse, after a year of being in service (see Table 3). The likelihood of an attempt failing at the time of sinking a well was on an average three times higher than a successful attempt even in 2005 (Table 4). Because most smallholders from the OBC Kurubas and Ekila castes have financed such expenditures through credit sourced informally, often from pioneering thota owners, they have been forced to take out more credit after facing failed attempts, make more desperate attempts, and have slipped into greater indebtedness relative to their marginal scale of production. As late-coming entrants into a tightly structured field of groundwater, such households have faced severe dis-accumulation due to irrigation costs that pro-reform writings, such as Joshi et al. (2004), tend to ignore.

Table 3 NRP; (av.) capital farm-expenditure (in Rs.) across peasant classes (2000-2005) per acre

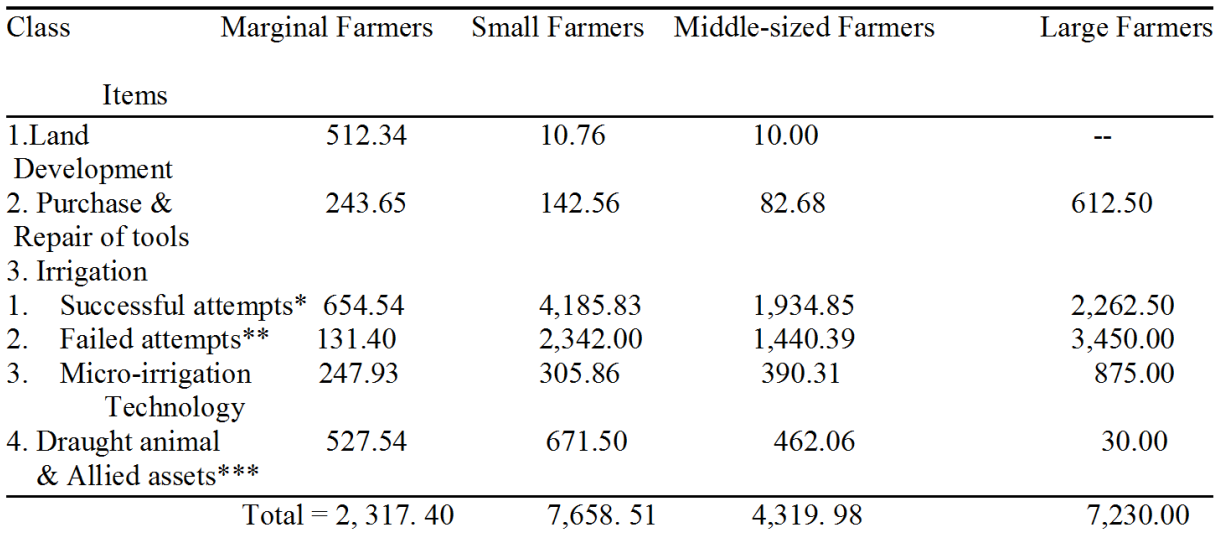

Note: * Costs of drilling, pump set, PVC and power connection combined. ** Includes attempts that were successful initially but where the well dried up in a year. ${ }^{* \star}$ Does not include investment in livestock for such households that heavily depend on livestock.

Source: NRP Household Sample Survey 2005-06 
Table $4 \quad$ Peasant classes; av. bore-well attempts per household (2000-2005)

\begin{tabular}{|c|c|c|c|}
\hline$\overline{\text { Class }}$ & $\begin{array}{l}\text { Attempts* } \\
\text { (No.) }\end{array}$ & $\begin{array}{c}\text { Successful attempts } \\
\text { (No.) }\end{array}$ & Success ratio** \\
\hline $\begin{array}{l}\text { 1. Marginal } \\
\text { Farmers }\end{array}$ & 1 & .33 & $1: 0.33$ \\
\hline $\begin{array}{l}\text { 2. Small } \\
\text { Farmers }\end{array}$ & 2.8 & .90 & $1: 0.32$ \\
\hline $\begin{array}{l}\text { 3. Marginal } \\
\text { Farmers }\end{array}$ & 3.3 & 1.05 & $1: 0.31$ \\
\hline $\begin{array}{l}\text { 4. Large } \\
\text { Farmers }\end{array}$ & 4.8 & 1.66 & $1: 0.34$ \\
\hline
\end{tabular}

In an agricultural space marked by intensifying commodity production on one the hand and variable and low access to groundwater on the other, it would seem inevitable that horticulture would produce a market in groundwater, since we know that "commodification is self-generating" (Salam 2015:154). Yet, as late as in 2008-09 such an outcome was unanticipated, for until then farmers preferred sinking individual borewells. Unlike in Gujarat and Tamil Nadu where stable groundwater markets had developed in the 1980s (Shah 1993; Mosse and Shivan 2003), two variants of socially structured exchange prevailed in NRP. In its mild form a dry-land farmer negotiated for water from his neighbor for a season-if both shared good social ties-under an equal input-output sharing arrangement (koru). But in several such cases the former eventually sank his own bore-well. The second form was strongly structured by the local "moral economy of security" (Scott 1977:5): depending on one's inter and intra-caste social capital, or on one's indigence (such as an individual facing a drought when his plants were ready to be harvested), one negotiated for water to be shared for days, even weeks, free of cost. Farmers spoke of groundwater as "Goddess Ganges" (Gangamma), whose presence in individual fields meant sacred luck granted to "individuals" (vyaktik adrushtam). Those flouting the norm of sharing water to an indigent neighbor were publicly censured as "selfish/unkind" (nisthuram). As the cost of individual attempts has risen, and as horticulturists across classes have seen negative fluctuations or a decline in their water yields, they have begun to set a price for buying water. Between 2014 and 2015, I recorded three such transactions, all of which were restricted amongst neighboring $\mathrm{OBC}$ and Reddy middle-class horticulturists; the transactions were said to have involved "distress" (taapatryam) for the buyers whose orchards faced an imminent withering; calculating the price involved estimating the average expected income for the buyer from the crop, demanding a "reasonable" share of it," and factoring in the buyer's reputation and industriousness and his skills in organizing his social circle to mediate on his behalf. Groundwater now appears to constitute a distinct "commodity" and "arena of exchange," admitting more horticulturists than dry-land farmers given the former's higher capital (and compulsion) to satisfy the asking price. Thus, following Bourdieu (2005), both the emergence and functioning of this field of exchange is a historical product of "an encounter between socially constituted individual dispositions and social structures" (p. 193). 


\section{Horticulture: masculinities under precarious production conditions}

Using Polanyi's (1944) concept of "embeddedness," the local horticultural shift is the latest instance of the capitalistic "disembedding" of Anantapur agriculture in a century's time: "disembedding" here refers to the widening ambit of agricultural inputs and services, genuine and "fictitious" (i.e. fashioned outside of the market) that are being provisioned through price-mechanism (pp. 43-44). But Polanyi entangles this historical dimension of embeddedness with another dimension, which is that market processes possess autonomous meanings (e.g. the notions of individual gain, remunerative work etc.) and organization (such as the factory system). His use of the concept is therefore dialectic in that the creation of autonomous market processes is inseparable from the constant socio-political necessity of reinforcing "primary fiction" and meanings and of undercutting any counter-moves that the fiction generates. This Polanyian dialectic has been complemented and interrogated through the demonstration that, although it is increasingly autonomous, the modern Market requires and draws on social structures and contingent, contested, cultures (Edelman and Haugerud 2011:30, 83; Salam 2015). I acknowledge here the two variants of the new "embeddedness" postulate, first that economic practices are embedded in social networks of weak ties (Granovetter 1973:137071), and second that markets are a historically structured field with variable habitués and capitals of agents (Bourdieu 2005:193-4)-to convey that my analysis is closer to Bourdieu's "structural embeddedness vision" of the economic field. This embeddedness for me lies in the way in which the local class and caste structures, and emerging cultural dispositions that interpret these structures, reshape the wider process of horticultural restructuring and recreate a local field of practices.

19 Two different qualifications to this "structural vision" are however in order. First, I follow M. N. Srinivas (2002:73) in suggesting that certain cultural norms undercut specific caste and class hierarchies in rural India just as others inhere in them. In the ethnographic context in question, for instance, common cultural bonds have included the ways in which many backward caste farmers have identified with the Reddy farming dispositions of "living well by cultivation" (rythu-pani) and with achieving great acumen ( telivi) in farming (see also Arnold 1998:77). Put differently, this qualification brings us close to analytical discussions on hegemonic cultural ideals and mimetic or subversive practices relating to gender and caste-class structures (e.g. Chopra, Osella, and Osella 2004:6; de Neve 2004; Mines 1992). Relatedly, I acknowledge the post-structuralist stance in gender theory that has interrogated the "essentialist and fixing nature" (Cornwall and Lindisfarne 2013:3) of the structuralist theories of identities by theorizing fluidity and constant performativity in the creation of gendered selves. These qualifications imply that the local gender system is construed here as a historically shaped structure with sets of normative ideals that are interpreted and realized variously in and across a person's life in given caste-class hierarchies. In the remainder of this paper, I focus on one aspect of the local gender-caste system, namely the relationship amongst middle and small $\mathrm{OBC}$ Kuruba and Ekila men as represented symbolically, within one arena of everyday gender practice-i.e. horticultural production. The other axes of gender structure, namely men-women relationships, and other arenas of everyday 
practices, such as consumption, are undeniably constitutive of this system but the demands of brevity constrain me to focus on this one aspect of the complex.

In 2005-06, I was accompanying my farmer friend Ramesh, a middle class Boya horticulturist (27 years) to visit his Kuruba friend Ujinappa (40 years) in KK village, located in a canal-irrigated mandal $22 \mathrm{~km}$ from NRP. KK is comprised of prosperous Kuruba peasantry that grows double-cropped paddy in low fields and Batavia in higher bore-well irrigated tracts, and this prosperity of the $\mathrm{OBC}$ households in KK has led it to be a "class uru" (developed village) in the eyes of the non-Reddy NRP peasants. As we were settling down at Ujinappa's house, Ramesh asked after his host's crops and the latter complained about the groundnut yield loss he had just suffered owing to pest attacks. Ramesh asked if Ujinappa had used pesticides. Shaking his head in dissatisfaction with the frequency of sprays Ujinappa reported, Ramesh said: "You should have sprayed chemicals more often, should have been more aggressive-as we are in our village!" (Inka aveshamnga mandulu kottala anna, mauur madriga.) This disposition of aggression, or avesham, Ramesh identified himself with is substitutable with another term, roshamu. These concepts convey two meanings locally; as an adverb, they prescribe and evaluate a person's (man or woman) willpower in pursuing his constitutive social duties; as an adjective, they evaluate a man's (or, a woman's) general "capacity" as a person, which includes his/her capacity to recognize an offence or challenge from a rival or a subordinate and respond suitably. These meanings are usually co-dependent in overlapping arenas of male life that range from house holding and farming (as in "so and so working with avesham") to community leadership (as in "he has grip on people"). Avesham is supposed to be regulated by a man's critical faculty (vicekshana). (Women are said to lack this faculty.) Thus, these concepts suggest that the distinctions of autonomy (i.e. responsibility for one's action) and pre-eminence, which Mattison Mines (1992:154) found to be important attributes of Indian personhood while rebutting Louis Dumont, are not yet irrelevant to NRP peasants. But these values often conflict with each other in many concrete situations, such as when a householder chooses to interpret a challenge from a rival or a subordinate as overriding his obligations for responsible house holding (see Subramaniyam's case below).

21 Besides masculinizing himself, Ramesh was thus masculinizing his dry land village and its cultivators by suggesting that they use inputs and make efforts more intensely to extract returns in unfavorable production conditions relative to KK village. This attribution of masculinity is indicative of the way in which the oft-heard injunction that "good yields require good investments" is used widely to evaluate a farmer's aggression and his claim of "loss/gain" in farming inside and across castes (Kumar 2017:238-39). An implication is that the emphasis on intensity of input consumption has nearly marginalized those selfpresentations in which NRP farmers, like farmers elsewhere in India (e.g. Gupta 1998; Vasavi 1994), have claimed individual and collective distinctions by taking yields without using industrial inputs or by mixing them judiciously with traditional inputs/practices on the grounds of the humoral specificities of their lands. In fact, many successful Ekila and Kuruba horticulturists in NRP who have sunk their bore-wells post 2000 and are Ramesh's cohort in this sense consider aggressive usage of inputs as a dispositional attribute that is superior to "reactive farming." From this new stance, a farmer is and ought to be aggressive about getting the best returns possible by constantly anticipating a variety of positive and negative contingencies-e.g. crop diseases or fluctuation in output prices-by using technology and social circles proactively rather than merely responding to events. 
Farmers privilege this stance as "mundu jagrata" (proactiveness). Hanging around input shops in the mandal bazaar, which are now both "workplaces" and sites of male bonding (Gutmann 1997:393), they see themselves as "aggressive-proactive" farmers across castes, unlike the "reactive farmers" who they say are either uninformed about inputs or who try to "save money" on them. In a conversation with this researcher in one such shop, from which many NRP horticulturists regularly purchased inputs on credit, some Ekila horticulturists characterized an older Reddy horticulturist from the Tupakula family as a "miserly, reactive farmer."

These attributions of masculinity through input commodities possibly illustrate a new metonymy that small horticulturists from the non-elite castes are claiming in their attempts for upward mobility in a precarious production setting (following Cornwall and Lindisfarne 2013:21; Connell 2005:255). They suggest that contemporary processes of production are but processes of consumption, defying conceptual attempts that draw too fine a line between the two in understanding contemporary capitalism (e.g. Comaroff and Comaroff 2011:178). Significantly, masculine attributions through input-consumption are often articulated through a well-established cultural idiom, which is also a specific dimension of aggression, called tiagam. Tiagam (an adverb) denotes a person's stubborn willingness to stake everything he has to achieve an honorific goal. Such goals have traditionally related to a person's constitutive familial roles, such as purchasing a highly coveted piece of land for one's male offspring, or, outside of the household, it has meant vanquishing an opponent in a factional or non-factional duel (see below). While retaining this familial aspect, tiagam increasingly refers to the general project of becoming a horticulturist by stubbornly looking for groundwater-arguably the most important commodity now. It is usually demonstrated by risking one's existing economic capital (family savings, jewelry, flock of ruminants) and social capital (institutionalized social standing and networks in the community [Bourdieu 1986]) by making multiple attempts at sinking bore-wells. Bore-well drilling is also a masculine affair in terms of its "participation framework" (Goffman 1981:3): that is, men as friends and relatives gather, stay, and make assessments of attempts during drilling, which can last for hours, usually through the night. I describe the case of Subramaniyam (30 years; a small Kuruba farmer) to illustrate this new metonymy of masculinity and ownership of groundwater as it emerged in a conversation with his friend:

V (respondent): He sank the first bore-well in 2000, but failed to find water. Same day, same time, he had the second attempt. But again no water. That day itself (he thought) that he would do this (i.e., commit suicide).

$\mathrm{N}$ (researcher): Why do you say that?

V: For three days, he disappeared from the village, went somewhere else. He said: I must live amongst four people, live with thota. He was an aggressive person (full tension manishi). In 2001, he sank another bore well, 100 feet (deep). It failed. Some fifteen days later, he tried another one, up to 250 feet; two-inch water was found. He planted 250 plants there. (But) within one year, water began decreasing. (Since) he thought plants would die now, he sank another bore (in 2002). At 290 feet, he found two and half inch water. With two bore-wells, he earned (Rs) 40,000 in 2006. And he planted another 250 plants.

$\mathrm{N}$ : Why again?

V: (He thought) "There is water, so more plants can be grown." But this year (2007), water began to go down fast. On February $1^{\text {st }}$, he called the drilling machine. They drilled up to 100 feet, unsuccessfully. He could not even pay them their charges, (Rs.) 5,000 was still due. Yesterday he went to the town alone. He did not even have the bus fare on him, took Rs. 200 (as credit) from someone, thinking that if water 
were found this time, someone would lend him. He called the drilling team without informing anyone in family. They tried first at one point but could not find anything. He asked them to drill at another place, but when it reached about 200 feet, he left the field saying he was going to attend nature's call. He went out in the dark and drank poison.

In an instance such as this one it could be argued that the imminent withering of an orchard would push anyone to sink multiple bore-wells, and that such attempts therefore instantiate situational distress (tapatryam) rather than manly tiagam. But Subramaniyam's friends interpreted his attempts as conveying precisely that for, "unlike many of his cohorts that had become quiet accepting their fate" (that they had possibly no scope to find groundwater after a few attempts), or, unlike others who could have gone to "beg/ request" water from neighbors (usually close kinsmen, as the case was here) in such a situation, he unyieldingly repeated drilling. They clearly saw the logic of all his action as "performing manliness at any cost," to use Herzfeld's phrase (1988:16), relative to other dry land farmers and to his kinsmen that are successful horticulturists. Showing tiagam through risk-taking in horticulture complicates any neat distinctions between performing masculinity successfully and failing at it. Also, to the extent that small $O B C$ horticulturists like Subramaniyam show their commitment to an aggressive masculinity generally associated with the Reddys, such cases complicate the idea that locally hegemonic forms of being a man, although internally contradictory, are irrelevant for the subalterns (Chopra et al. 2004:14).

The "performances of exception" amongst $\mathrm{OBC}$ farmers through metonymic associations and the caste, class and gender structures underpinning them are configured in the way horticulture is now the "crop of competition" (poti-pantalu). To show how meaningful the term poti is locally, let me briefly allude to the events around the sale of the harvested Batavia in mid-2015. A. Adanna (45 years), a middle class Kuruba horticulturist with an 8acre thota with 1,300 plants, had sold his summer harvest of 80 tons for Rs. 17, 46,000. Barely two months later, Satyamaiah, a Boya horticulturist with a 3-acre grape thota with 200 plants, sold his harvest of 30 tons of grapes for Rs. 15, 00,000. The news of these sales from NRP, and sales such as these from other villages, was circulated in the mandal as "records." Such "records," on the one hand, distinguished the caste-ness of the concerned farmers, for it was widely held in NRP that the only two households in the village that could ever be imagined with farm-incomes of this scale were from the Tupakula family. The Kurubas and Ekilas, on the other hand, also evaluated these "records" as individual performances crisscrossing caste boundaries on a new metric of efficiency: Adanna's income was found to be "superior" to the income of all other Batavia farmers, including Tupakula P. Reddy's, the Reddy landlord with 1,500 plants on his 10-acre thota, but it was "inferior" to Satyamaiah's income because the latter had earned 15 lakhs $^{10}$ from "merely 200 plants." General competition amongst horticulturists on this metric of farm-efficiency, based as it is on gross receipts per plant for an individual, appears to be using and extending the local concept of poti in a new political economy that valorizes risk-taking at every step.

The notion of poti represents both an objective social state and a subjective consciousness amongst local farmers of being individuals-in-competition in the "new farming." In such a state, if a claim or assessment of performative excellence of individual is made, it is based on ex post facto comparisons of farming incomes. But poti of a particularized form-a sort of duel-is also possible when men of roughly equal capitals (such as kinsmen) compete with pre-mediated strategies to beat one another. The villagers avidly remember 
a duel between two married brothers from the Tupakula family, who competed against one another in the 1980s to acquire lands in the village, produce greater groundnut yields, and increase their influence over the laboring men of other castes. In keeping with the analysis of rivalries that has been offered in the anthropology of the family, such as that of Pocock (1975:14) and Parry (1979), this instance had its origin in the contradiction of role-related performances amongst married men as brothers and fathers. But unlike in Gujarat or the Kangra Valley, Pocock and Parry's respective fieldwork sites, upper-caste rivalries in Anantapur (and Rayalaseema in general) have historically also been about local Reddy and Kamma notables competing for political dominance (Elliot 1995). Of such famed rivalries the most recent examples are the Bhuma Reddy family, locked in an intergenerational rivalry with the Gangula Pratap Reddy family in the Kurnool district, and Paritala Ravi's (a Kamma) rivalry with M. Suryanarayana Reddy in Anantapur, both of which were replete with assassinations and counter assassinations (Radhakrishna 2017). What seems to be novel about particularized poti in our context is that (1) it is the upwardly mobile bore-well owning horticulturists from the $\mathrm{OBC}$ castes who increasingly engage in duels at smaller scales, and (2) horticultural activities have been incorporated as sites for such duels. In one instance of this "incorporation" two patrilineal kinsmen amongst the Ekilas, J. Chalapathi and G. Shivaiah, challenged one another in the village bazaar to obtain higher yields of chili in their orchards. Following this challenge, they often announced the usage of fertilizer and chemicals in their fields in the bazaar. Shivaiah claimed, and was acknowledged by others, to have won the challenge at the end of the crop season. Although it involved groundnut, another duel in 2013 exhibited similar incorporation:

Muniswami, a middle scale Ekula farmer, had produced 36 bags of groundnut pods (45 kg each) in an acre in his thota. (This is $1,620 \mathrm{~kg} / \mathrm{acre}$, five times the average village level yields in dry land conditions.) It was a record. Ramesh got into competition with him mentally. In the next Rabi (i.e. winter) crop in 2014, Ramesh did groundnut in one acre and got 40 bags but Muniswami got 146 bags in 4 acres, or 36 bags in one acre. Ramesh publicly claimed he got better yield than Muniswami. Muniswami retorted, "If you had planted the crop in 4 acres then you would have seen it. Do it in 4 acres and see." Ramesh dared him, "You too do just 1 acre and show me a better yield." For about 10 days, they did not talk to each other after this altercation.

The disposition amongst the Kurubas and Ekilas to engender themselves as successful horticulturists in an unstable field of production requires them to think of creating and maintaining networks as a valuable activity. Given the importance of credit, water, and chemicals as key inputs, creating and maintaining a social network around them has become crucial. In such networks, albatlu-"friends and acquaintances"-are distinguished from kinship ties: the former includes people from outside of one's own caste and village in addition to one's friends within the caste, largely based on shared interests and dispositions. Kinship ties, however, act as an important contributor to one's albatlu network outside of one's village. In this sense, albatlu seems to instantiate Bourdieu's (1986) concept of social capital that he defines as a "network of more or less institutionalized relationships of acquaintance and recognition" (p.21). The importance of such networks in the contemporary production process was first visible to me when I found that, across classes, the local peasants attributed a significant share of their borrowings (and lending) to albatlu and that these sometimes included one's former or current employers too. A detailed account of the structure of albatlu is not possible here. What may be emphasized is the mediation by such networks of one's participation in 
markets, and the skills and capacities required to maintain such networks. Having a network of albatlu solves the fundamental problem of information asymmetry and risks about borrowers in the intra-village informal credit market because such friends act as "referees" or even "guarantors" (jamin). Such networks invoke the normative ideals of masculinity combined with one's caste and class-positions: whether one is a jamin or a borrower or lender in such networks, one's reputation of "sticking to one's words" and one's "industriousness" are emphasized alongside one's caste and economic status. Of course, maintaining such networks also requires higher pecuniary capacity for spending on social outings, alcohol, and cigarettes.

It may now be asked if this case study of the formation of subaltern masculinities through risky horticulture illustrates an embedding of the wider "neoliberal enterprise culture" that has been documented elsewhere in India and the West (e.g. Gooptu 2016:7; Rose 1998:151). For Gooptu (2016), "enterprise culture" is a form of public culture that celebrates and seeks to recreate "individuals" who cultivate "initiative, energy, independence, risk-averseness..." in all "walks of life" including their "own self," to maximize their interests (pp.4-8). This work argues that, post-liberalization, there has been a concerted effort at creating such a culture "from above," i.e. through state policy instruments, corporate firms, or films, but it is being adopted selectively or even resisted at the "bottom," depending on one's biography on the metrics of class, spatiality, and gender. Whether it is the youth in Bangalore's IT sector or workers from provincial towns seeking employment at call centers in Delhi, they selectively use "entrepreneurial training programs" (Upadhya 2016:95) to fit better into their work-places and to pursue upward mobility for themselves and their families even as they develop a grounded critique of such programs (Upadhya 2016; McGuire 2016). At the general politicoeconomic level, $\mathrm{OBC}$ horticulturists in NRP are also forging "proactiveness" and "commercial calculability" in and through the commodity market, but the modes of entrepreneurial messaging are less direct here (e.g. through the regional media and farminput markets). Supporting Gooptu (2016:7), I suggest that this new "entrepreneurial self" in NRP embeds the local, historically evolved configurations of caste and class hierarchies. But my ethnographic evidence also underscores the fact that the local idioms of masculinity have incorporated conventional notions of achievement-oriented individuality, as Mines argued quite some time ago (i.e. 1992), which underlie the emergence of the new entrepreneurial culture and give it an immediate cultural intelligibility.

\section{Conclusion}

The historical process of intensifying commodity farming in semi-arid Anantapur has benefited the large Reddy farmers and some wealthy OBC farmers, who have formed the core of the local agrarian structure due to their superior access to land and groundwater. I have presented evidence of restructuring in this elite class over the last two decades: while backward-caste Ekilas have become successful horticulturists in the village, the numerically predominant Kurubas have experienced growing income inequality on the basis of changing access to groundwater. Small Kuruba landholders face ruinous social costs of groundwater exploitation in the form of a high failure rate at bore-well attempts. These trends give us grounds to doubt whether the policy of pushing horticulture as a general rural development strategy on the basis of private investment in groundwater is 
socially and ecologically sound. The second major conclusion the paper advances concerns the economy-culture connections. I have suggested that many locally backwardcaste smallholders employ the locally exalted norms and practices of masculinities within horticulture, such as showing (and applauding) aggression in input usages, taking risks, and waging competition with their rivals within and across castes. Some of them manage to engender themselves varyingly as "exceptional farmer-men" locally. Following these masculine practices-some of which have been associated with the dominant Reddy caste -helps these smallholders adopt horticulture in unfavorable economic and ecological conditions and learn the wider entrepreneurial values of the new "market society." Simultaneously, these practices also create the possibility for performative failures for many men amongst these castes.

\section{BIBLIOGRAPHY}

Akram-Lodhi, Haroon A., and Christopher Kay. 2010. "Surveying the Agrarian Question (part 2): Current Debates and Beyond." The Journal of Peasant Studies 37(2):255-84.

Alaev, Leonid Borisovich. 2012. "South India." Pp. 226-34 in The Cambridge Economic History of India, Vol. 1: c. 1200- c. 1750, edited by D. Kumar and I. Habib. New Delhi: Orient Black Swan.

Alagh, Yoginder K. 2006. "Indian Economic Strategies after Doha." Pp. 205-32 in India in a Globalizing World: Essays in the Honour of C. H. Hanumantha Rao, edited by R. Radhakrishna, S. K. Rao, and S. Mahendra Dev. New Delhi: Academic Foundation.

Arnold, David. 1998. "Famine in Peasant Consciousness and Peasant Action: Madras, 1876-8." Pp. 62-115 in Subaltern Studies. Vol. 3, edited by R. Guha. Delhi: Oxford University Press.

Banaji, Jairus. 1996. “Globalisation and Restructuring in the Indian Food Industry.” The Journal of Peasant Studies 24(1-2):191-210.

Bhalla, G. S. 2006. “Agricultural Growth and Regional Variations.” Pp. 309-46 in India in a Globalising World: Some Aspects of Macro Economy, Agriculture and Poverty, Essays in Honour of Prof. C. H. Hanumantha Rao, edited by R. Radhakrishna, S. K. Rao, and S. Mahendra Dev. New Delhi: Academic Foundation.

Bourdieu, Pierre. 1986. "The Forms of Capital.” Pp. 241-58 in Handbook of Theory and Research for the Sociology of Education, edited by J. Richardson. New York: Greenwood.

Bourdieu, Pierre. 2005. The Social Structures of the Economy. Cambridge: Polity Press.

Bourdieu, Pierre. 2001. Masculine Domination. Stanford: Stanford University Press.

Byres, Terrence J. 1995. "Political Economy, the Agrarian Question and the Comparative Method." The Journal of Peasant Studies 22(4):561-80.

Chand, Ramesh, S. S. Raju, and L. M. Pandey. 2007. "Growth Crisis in Agriculture: Severity and Options at National and State Levels." Economic and Political Weekly 42(26):2528-33.

Chief Planning Officer. 2010/2011-2014/15. Handbook of Statistics. Anantapur: District Collectorate. 
Chief Planning Officer, Government of Andhra Pradesh, Anantapur. 2011. Handbook of Statistics. Anantapur: District Collectorate.

Chopra, Radhika, Caroline Osella, and Filippo Osella, eds. 2004. South Asian Masculinities: Context of Change, Sites of Continuity. New Delhi: Kali for Women.

Comaroff, Jean, and John Comaroff. 2011. "Millennial Capitalism and the Culture of Neoliberalism." Pp. 177-88 in The Anthropology of Development and Globalization: From Classical Political Economy to Contemporary Neoliberalism, edited by M. Edelman and A. Haugerud. Malden, MA: Blackwell.

Connell, Robert William. Masculinities. Berkeley; Los Angeles: University of California Press.

Cornwall, Andrea and Nancy Lindisfarne, eds. 2013. Dislocating Masculinity: Comparative Ethnographies. Routledge: Oxon.

De Neve, Geert. 2004. "The Workplace and the Neighborhood: Locating Masculinities in the South Indian Textile Industry." Pp. 60-95 in South Asian Masculinities: Context of Change, Sites of Continuity, edited by R. Chopra, C. Osella, and F. Osella. New Delhi: Kali for Women.

Dubash, Navroj K. 2004. Tubewell Capitalism: Groundwater Development and Agrarian Change in Gujarat . Delhi: Oxford University Press.

Edelman, Marc, and Angelique Haugerud, eds. 2011. The Anthropology of Development and Globalization: From Classical Political Economy to Contemporary Neoliberalism. Malden, MA: Blackwell.

Elliot, Carolyn M. 1995. "Caste and Faction among the Dominant Caste: The Reddis and Kammas of Andhra." Pp. 121-64 in Caste in Indian Politics, edited by R. Kothari. Hyderabad: Orient Longman.

Farmer, Ben H., ed. 1977. Green Revolution? Technology and Change in Rice-growing Areas of Tamil Nadu and Sri Lanka. London: Macmillan.

Francis, W. 1905. The Gazetteer of Anantapur District. Madras: Addison \& Co.

Friedmann, Harriet. 1993. "The Political Economy of Food: A Global Crisis." New Left Review 197:29-57.

Goffman, Erving. 1981. Forms of Talk. Philadelphia: University of Pennsylvania Press.

Ghose, Jayati. 2005. “The Indian Economy (1970-2003).” Pp. 1027-46 in The Cambridge Economic History of India, Vol. II: c. 1757-2003, edited by D. Kumar and M. Desai. New Delhi: Orient Longman.

Gutmann, Mathew C. 1997. "Trafficking in Men: The Anthropology of Masculinity.” Annual Review of Anthropology 26(1):385-409.

Government of India. 2017. Economic Survey 2016-17. New Delhi: Ministry of Finance.

Government of India. 2014. Indian Horticultural Database 2014. New Delhi: Ministry of Agriculture. Granovetter, Mark S. 1973. “The Strength of Weak Ties.” American Journal of Sociology 78(6):136080.

Gooptu, Nandini, ed. 2016. Enterprise Culture in Neoliberal India: Studies in Youth, Class, Work and Media. New York: Routledge.

Fan, Shenggen, and Ashok Gulati, eds. 2007. The Dragon and the Elephant: Agricultural and Rural Reforms in China and India. New Delhi: Oxford University Press.

Gupta, Akhil. 1998. Postcolonial Developments: Agriculture in the Making of Modern India. Durham: Duke University Press. 
Harriss-White, Barbara. 2008. “Introduction: India's Rainfed Agricultural Dystopia.” The European Journal of Development Research 20(4):549-61.

Harriss-White, Barbara and Graham Chapman. 1984. Exchange Relations and Poverty in Dryland Agriculture: Studies of South India. New Delhi: Concept Publishing Company.

Harriss-White, Barbara and S. Janakrajan. 2004. Rural India Facing the $21^{\text {st }}$ Century: Essays on Long Term Village Change and Recent Development Policy. London: Anthem Press.

Harriss-White, Barbara and S. Janakarajan. 1997. "From Green Revolution to Rural Industrial Revolution in South India." Economic and Political Weekly 32(25):1469-77.

Harriss-White, Barbara. 2008. Rural Commercial Capital: Agricultural Markets in West Bengal. New Delhi: Oxford University Press.

Herzfeld, Michael. 1988. The Poetics of Manhood: Contest and Identity in a Cretan Mountain Village. Princeton: Princeton University Press.

John, Mary E. 2015. "Rejection or Critical Dialogue? Intersectionality." Economic and Political Weekly 50(33):72-76.

Joshi, P. K., Ashok Gulati, Pratap S. Birthal, and Laxmi Tewari. 2004. “Agriculture Diversification in South Asia: Patterns, Determinants and Policy Implication." Economic and Political Weekly 39 (24):2457-67.

Kannan, Elumalai and Sujata Sundaram. 2011. “Analysis of Trends in India's Agricultural Growth.” Working Paper No. 276. Bangalore: Institute of for Economic and Social Change.

Karanth, K. R. 1987. Ground Water Assessment: Development and Management. New Delhi: Tata McGraw-Hill Education.

Kotwal, Ashok and Bharat Ramswami. 1998. "Economic Reforms of Agriculture and Rural Growth." The Journal of Policy Reform 2(4):369-402.

Kumar, Dharma. 1992. Land and Caste in South India: Agricultural Labour in the Madras Presidency during the Nineteenth Century. New Delhi: Manohar Publishers.

Kumar, Nilotpal. 2017. Unraveling Farmer Suicides in India: Egoism and Masculinity in Peasant Life. New Delhi: Oxford University Press.

Lerche, Jens. 2015. "Regional Patterns of Agrarian Accumulation in India." Pp. 46-55 in Indian Capitalism in Development, edited by B. Harriss-White and J. Heyer. London: Routledge.

Little, Peter D. and Catherine S. Dolan. 2011. "Non-traditional Commodities and Structural Adjustment in Africa." Pp. 206-25 in The Anthropology of Development and Globalization: From Classical Political Economy to Contemporary Neoliberalism, edited by Marc Edelman and Angelique Haugerud. Oxford: Blackwell Publishing.

Ludden, David. 1999. An Agrarian History of South Asia. Cambridge: Cambridge University Press.

McGuire, Meredith L. 2016. "The Embodiment of Professionalism: Personality-Development Programmes in New Delhi." Pp. 109-23 in Enterprise Culture in Neoliberal India: Studies in Youth, Class, Work and Media, edited by N. Gooptu. New York: Routledge.

Mines, Mattison. 1992. "Individuality and Achievement in South Indian Social History." Modern Asian Studies 26(1):129-56.

Mosse, David and M. Shivan. 2003. The Rule of Water: Statecraft, Ecology and Collective Action in South India. New Delhi: Oxford University Press. 
Ninan, K. N. 1987. "Edible Oilseeds: Growth and Area Responses." Economic and Political Weekly 22 (39):A97-A110.

Parry, Jonathan P. 1979. Caste and Kinship in Kangra. Cambridge: Cambridge University Press.

Pred, Allan and Michael Watts. 1992. Reworking Modernity: Capitalisms and Symbolic Discontent. New Brunswick: Rutgers University Press.

Polanyi, Karl. 1944. The Great Transformation: The Political and Economic Origins of Our Time. Boston: Beacon Press.

Pocock, David. 1975. Mind, Body and Wealth: A Study of Belief and Practice in an Indian Village. Oxford: Basic Blackwell.

Radhakrishna, G. S. 2017. "Factionalism, Violence and Politics in Andhra Pradesh's Rayalseema." The Wire, March 31. Retrieved July 16, 2017 (https://thewire.in/119193/rayalaseema-politicsandhra-pradesh/).

Rose, Nikolas. 1998. Inventing Our Selves: Psychology, Power, and Personhood. Cambridge: Cambridge University Press.

Salam, Umar. 2015. "Commodification, Capitalism and Crisis." Pp. 153-69 in Indian Capitalism in Development, edited by B. Harriss-White and J. Heyer. London: Routledge.

Satyanarayana, G. 2005. “Expansion of Commodity Production and Agrarian Market." Pp. 182-238 in Agricultural Production and South Indian History, edited by D. Ludden. New Delhi: Oxford University Paperbacks.

Satyanarayana, A. 1965. The District Gazetteer of Anantapur. Hyderabad: Government of Andhra Pradesh.

Scott, James C. 1977. The Moral Economy of the Peasant: Rebellion and Subsistence in Southeast Asia. New Haven: Yale University Press.

Shah, Tushar. 1993. Groundwater Markets and Irrigation Development. New Delhi: Oxford University Press.

Shankari, Uma. 1991. "Major Problems in Minor Irrigation: Social Change and Tank Irrigation in Chittoor." Contributions to Indian Sociology 25:85-111.

Srinivas, Mysore N. 2002. Collected Essays. New Delhi: Oxford University Press.

Subrahmanyam, S., and P. Satya Sekhar. 2003. "Agricultural Growth: Pattern and Prospects." Economic and Political Weekly 38(12/13):1202-11.

Thurston, Edgar. [1909] 2001. The Castes and Tribes of Southern India. Vol. 1-4. New Delhi: Asian Educational Service.

Upadhya, Carol. 2016. "Shrink-wrapped Souls: Managing the Self in India's New Economy." Pp. 93-108 in Enterprise Culture in Neoliberal India: Studies in Youth, Class, Work and Media, edited by N. Gooptu. New York: Routledge.

Vasavi, Anninhalli R. 1994. "Hybrid Times, Hybrid People: Culture and Agriculture in South India." Man 29(2):283-300.

Washbrook, David. 1994. "The Commercialization of Agriculture in Colonial India: Production, Subsistence and Reproduction in the 'Dry South,' c. 1870-1930." Modern Asian Studies 28(01):12964.

Washbrook, David. [1976] 2008. The Emergence of Provincial Politics: The Madras Presidency 1870-1920. Cambridge: Cambridge University Press. 
Washbrook, David. 1975. "The Development of Caste Organizations in South India: 1880-1925." Pp. 150-203 in South India: Political Institutions and Political Change 1880-1940, edited by C. J. Baker and D. A. Washbrook. Macmillan: Madras.

Washbrook, David. 1973. “Country Politics: Madras 1880 to 1930.” Modern Asian Studies 7(3):475531.

Watts, Michael J. 2010. "The Southern Question: Agrarian Questions of Labor and Capital." Pp. 262-87 in Peasants and Globalization: Political Economy, Agrarian Transformation and Development, edited by A. H. Akram-Lodhi and C. Kay. Oxon: Routledge.

Whitecomb, Elizabeth. 2005. "Irrigation." Pp. 677-736 in The Cambridge Economic History of India, Vol. II: c. 1757-2003, edited by D. Kumar and M. Desai. New Delhi: Orient Longman.

World Bank. 2008. The World Development Report: Agriculture for Development. Washington D.C.

\section{NOTES}

1. The actual name of the village is anonymized. NRP is located $27 \mathrm{~km}$ from the district headquarters. It is a hamlet of larger revenue in the administrative sense.

2. The region consisting of Anantapur, Kadapa, Kurnool and Chittoor districts in southern AP.

3. Only 10 per cent of Anantapur was under forest cover in 2011 (Chief Planning Officer, Government of Andhra Pradesh, Anantapur 2011:61).

4. Harris-White and Chapman (1984:37) estimated an average unit in the district to be 9.6 acres.

5. As per the definitions used in the Handbook of Statistics (Chief Planning Officer, Government of Andhra Pradesh, Anantapur 2011).

6. In 2010 Anantapur claimed more than 50 per cent of the gross groundnut acreage in AP.

7. District Handbook of Statistics (Chief Planning Officer, Government of Andhra Pradesh, Anantapur 2011) and Kumar (2017:87).

8. These 7 patrilineal brothers include a tax official and a government schoolteacher. These two moved to Hyderabad in the 1980s. Of the remaining five, one has three sons; the first one runs a fertilizer shop in the mandal headquarters, the second has been working in the US since 2002 and the third is reportedly running a business in Guntur district. One of these 7 brothers, RK Reddy, was also the sarpanch of the local panchayat, representing the Congress Party, from 2010 to 2014.

9. Differences marked the estimates between the two sides but in two of these cases the prices agreed on were $10 \%$ of the average income estimated from the crop (i.e. Rs. 40,000-50,000)

10. 1 lakh rupees is one hundred thousand rupees in the Indian numbering system.

\section{ABSTRACTS}

India has seen a deceleration in the area and yield growth rates of many food and cash crops since the 1990s. The area and production of horticulture has, however, grown impressively in the post-liberalization period. This paper is a case study of this "restructuring" in a semi-arid village in Andhra Pradesh from a longue durée perspective. It suggests that horticulture has enabled a 
small class of pioneering Reddy farmers and some Kuruba farmers (a local "Backward Caste") who have better access to groundwater-to reinforce their economic position in the village. But a majority of small $\mathrm{OBC}$ dry-land farmers, the late-coming aspirants, are being excluded from horticulture due to the ruinous cost of groundwater. The paper contends that by recreating established idioms of aggressive masculinity, the aspiring $\mathrm{OBC}$ horticulturists construe horticulture as an arena in which to perform as virile, risk-taking "new farmers" to transact honor with other horticulturists and dry-land farmers within and across castes.

INDEX

Keywords: agrarian restructuring, horticulture, semi-arid India, caste, rural masculinity

\section{AUTHOR}

\section{NILOTPAL KUMAR}

Azim Premji University, Bangalore 